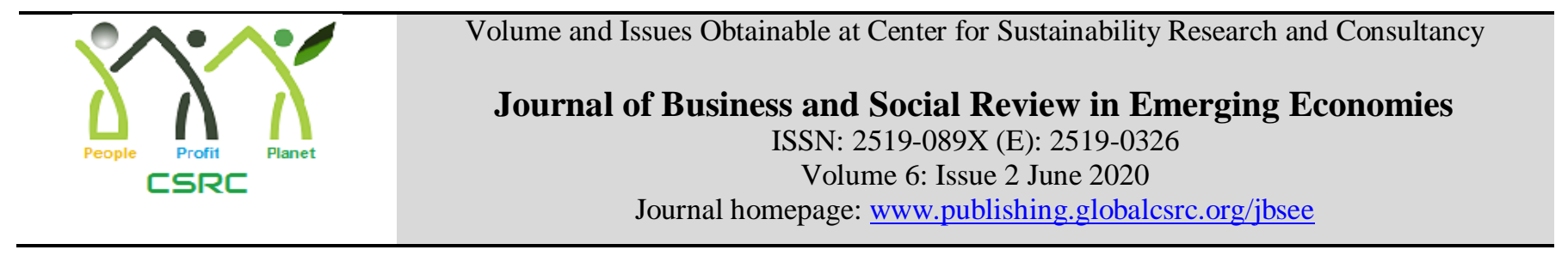

\title{
Lexical Borrowing in Print Media: Bilingualism in English Newspapers of Pakistan
}

\author{
${ }^{1}$ Malik Adnan, ${ }^{2}$ Muhammad Bilal Nawaz, ${ }^{3}$ Shehla Jabeen, ${ }^{4}$ Muhammad Shahzad \\ ${ }^{1}$ Department of Media Studies, The Islamia University of Bahawalpur, Pakistan, dr.adnan@iub.edu.pk \\ ${ }^{2 \& 3}$ Assistant Professor, Department of Mass Communication, Lahore College for Women University, \\ Jhang Campus Pakistan \\ ${ }^{4}$ Assistant Professor, Department of Media Studies, The Islamia University of Bahawalpur \\ Pakistan
}

\begin{tabular}{l}
\hline ARTICLE DETAILS \\
\hline History \\
Revised format: May 2020 \\
Available Online: June 2020 \\
\\
\hline Keywords \\
Lexical Borrowing, Loan \\
words, Urdu, Language, \\
English, Newspaper, \\
Pakistan \\
\hline
\end{tabular}

JEL Classification

MOO, M31

\begin{abstract}
English has been considered as one of the most useful spoken language and is referred as Lingua Franca all around the globe. English is the major source for communicating all over the world. In different cultures mostly people speak their native language but use English as an alternate. This paper explains the lexical borrowing that means the explanation about some words from Urdu that has turned out to be part of the English language in newspapers of Pakistan. In this regard, the most circulated and popular English Newspapers of Pakistan, The Nation and The News were selected to analyze the words from Urdu being normally used in the English language. One year period from 1st January to 31 st December 2019 has been selected for this research. The researchers draw from the categories of hard and soft news, formed by Tuchman in 1973, in the selected newspapers. The basic theme of this study is that finding the Urdu words that have become part of English language in Pakistani circumstances. This is a study of Urdu borrow words that got their way in English in daily communication and concludes that there are a variety of Urdu terms that have been used in the English language for communication in English newspapers of Pakistan.
\end{abstract}

(C) 2020 The authors, under a Creative Commons AttributionNonCommercial 4.0

Corresponding author's email address: dr.adnan@iub.edu.pk

Recommended citation: Adnan, M., Nawaz, M. B., Jabeen, S., Shahzad, M. (2020). Lexical Borrowing in Print Media: Bilingualism in English Newspapers of Pakistan. Journal of Business and Social Review in Emerging Economies, 6(2), 597-603

\section{Introduction}

Borrowing in the linguistic has been termed as the word that is used or transferred from other languages and used in a particular language. The borrowed word is known as borrowing, loanword or a borrowed word. For the existing vocabulary of English, approximately 120 languages have served as sources 
(Sebba, M. 2012). In these days, English is serving as a major donor to other languages and is the main source that leads to borrowing other languages' words. When two languages come into connection with each other, they not only share each other's vocabulary but also the meanings and features of words, i.e. syntactic, phonemes and morphemes features. When a lexical item is borrowed by the other language, the language that receives is called receiver language and the other language which donates is donor language (Braj B. Kachru, 2011). The speaker uses these words to make a better understanding of people so that they can understand in which context the word has been used. The crack in need borrowing is known as essential borrowing. The words that are already the part of donor language after the lexical borrowing they become the part of receipt language (Routledge, 2006). Pakistani English is one of the widely used postcolonial varieties of English language. English newspapers in Pakistan have been circulating effectively the transmission of messages, views, ideologies and observations throughout the country for long. Identifying with the progression of a collection of the language, these newspapers have not grasped any uniform strategy, as they are based more on passing on the message to the overall population (Baumgardner, R. 1993).

\subsection{Significance of the Study}

As the newspaper has become the daily need of people because their day starts with the reading of the newspaper. Also, the newspaper is the best way to enhance linguistic skills because the newspaper uses proper language and words to explain a particular scenario. The newspapers are global papers having information of the entire World and whenever a newspaper is picked up by a reader, the first sight goes to the content of the newspaper (Bhatia, T.K., \& Ritchie, W.C. (2004). The significance of the study is that it will help to understand the various Pakistani language varieties. It will also give us an idea as to what extent Urdu words have been used in Pakistan's English newspapers. The Urdu language is our primary concern and there are a variety of Urdu words in Pakistani English. These are the words most used in everyday conversation. Moreover, it will also help to analyze how English newspapers are playing their role by carrying a hole between Standard English and Pakistani variety.

\subsection{English Language and Bilingualism}

English language is a hybrid and flexible language and philological contact has been a main drive of transformation in it. At the early phases, it borrowed easily from Latin and Celtic, after at a later phase from French and Scandinavian and more recently from other languages pronounced in the British colonies. As this feature of English language makes it grow and expand rapidly. Several countries and regions have different English slangs and spellings. Numerous countries and nations are creating their own variety of languages. As Hong Kong has their own phonology of English words, whereas Singapore has its own pronunciations for words. Singapore has proved that they do not depend on the standard language not even for pronunciations. Because of huge Linguistic range and bilingualism, English variety has become a complex phenomenon (Deterding, D. 2007).

Shen, C. (2010) stated that there is a great effect of native language on English speakers. As English speakers when speak English language, they use the words of their native language which help them to communicate their ideas in a better way. Baumgardner, (1993) described that a non-speaker uses his own desired words to speak, since the users speak their own words as they have the choice to use the words of their local languages.

Due to bilingualism and cultural influence in Pakistan, English newspapers contain Urdu language words. The transformation of Urdu words in English newspapers in Pakistan has introduced new variety which can be recognized as various linguistic grammar terms, the formation of words, and lexical borrowing or lexical variation. The Urdu language is basically a mixture of many languages such as Arabic and Persian. In English newspapers of Pakistan, Urdu is a donor language and English is a recipient language. The basic research objective of current study is to point out some Urdu words in English newspaper of Pakistan. 


\subsection{Lexical Borrowing and Bilingualism}

Lexical borrowing is the process that enables two languages to donate their words, one language acts as a donor while others act as a receiver. This way the language changes while adopting each other's words. In addition to so it falls into, bilingualism and borrowing of words too. Every language has its own unique characteristics which enable the process of borrowing which absorbs the features of other languages and no modification does happen in the native language (Akhtar, H. et., all. 2018). Individuals use another language for the contextual need to join some other language's features and this process is known borrowing as divided the lexical borrowing into two categories, cultural borrowing and dialect borrowing. The dialect borrowing is coming from the same speech while cultural borrowing comes by contracting different languages (Kachru, B B. 1986). The concept of borrowing refers to the probability that certain linguistic elements are integrated into another language. Bilingualism and inter-lingual lexical phenomena on numerous theoretical grounds has been a challenging task to distinguish between borrowing, code swapping, and code mixing. While multiword insertions of other languages can be unambiguously categorized as code-switches, the categorization has long been the subject of discussion in studies of bilingualism and several scholars have argued for a less strict distinction between the different terms (Bhatia,T.K. 1992).

Multiple code changes showing borrowing properties based on their results, they proposed the noon borrowing category between borrowing and code-switching in addition to proposed four key criteria for determining the loanword status. Because embedded phrases are typically in the word order of the embedded language defined as more than one word, they can be code switched like longer inserts and embedded forms appear frequently in barren forms, which mean they do not have the moral influences needed to be included in the language of the matrix (Kia, L. S. et al. 2011). A contrasting view of why word foreign language incorporation as code switches should be treated as a single word is provided by as they are pronounced through embedded language phonology as they are not phonologically incorporated into the matrix language, they specifically represent code switches, because most known lexical borrowings are articulated in their language: that is to say, they are completely or at least partially integrated with the language obtained. This is true of the recipient language and gives additional proof that they are not borrowing but rather code-switches (Martin (1998). The lexical borrowing is characterized as the incorporation of foreign elements into the clause irrespective of the degree of phonological integration without attempting to solve these complex terminological and theoretical debates. The status of external language elements could be established the identified dimensions and same continuum as borrowing and code swapping, which is not purely linear but complex (Mushtaq, H. \& Zahra, T. 2012). Lexical communication phenomena develop from theoretical linguistics into lexical loan words and indigenous developments. It is based on whether the lexical objects in question are or not modeled on the donor language as lexical borrowing consists of some aspect of the language of donors, whereas creations are entirely original and have no counterpart in the language of the donor (Rebuck, M. 2001).

The Nation and The News are very popular and influential English language newspapers because it is the most widely circulated newspaper in any part of Pakistan. The English newspapers have however adopted international linguistics as a way to recognize the difference between Standard English and Pakistani variation. There are definite forms and contours for English language which is used by various people belonging in different societies. In his local Language dialect, English has rented several words. So bilingualism and lexical borrowing is a major research topic in linguistics and communication studies in Pakistan.

\subsection{English Newspapers in Pakistan}

In Pakistan print media especially English newspapers are more responsible and playing their role in transformation of the society too. The News and The Nation are the newspapers in Pakistan that are widely circulated. The Nation is published by the Nawaiwaqt group and The News is published by the 
Jang group.

\section{Research Methodology}

For content analysis of two English dailies The Nation and The News from Pakistan have been selected. The criteria for their selection included that both are leading English newspaper in Pakistan as well as have vast readership in the society and also popular among the policy makers. To keep in mind the nature of the topic, the technique of content analysis would be applied in order to accomplish the research study. For the present study unit of analysis are the news items related to lexical borrowing and bilingualism which are published in selected English dailies. One year period from $1^{\text {st }}$ January to $31^{\text {st }}$ December 2019 has been selected for this research. The unit of analysis in this research would be the complete news stories appeared on front, last and inside pages. The news stories as a whole served a contextual unit. The frequency of using borrowed words is checked and highlighted the Urdu words in news stories in selected English dailies. The researcher draws from the categories of hard and soft news, formed by Tuchman in 1973, in the selected newspapers. One of the first distinctions in the area of news was reported by the sociologist, Guy Tuchman, identified key concepts in the news production process and conceptualized the practice based on the perspectives of professions. She noted inter alia the distinction prevalent among professionals between "hard news and stories that interest humans" and between "soft" news which is interesting because it concerns the lives of people. "Hard" news primarily concerns issues including politics, economics, international relations, welfare and scientific developments, while "soft" news focuses primarily on human interest stories, gossip, etc (Tuchman, 1973). Within the context of this study, news stories are categorized and coded according to the two broad categories: hard and soft news.

\section{Results and Analysis}

Table No: 1

Total Urdu Barrowed Words in the Newspapers

\begin{tabular}{lll} 
Sr. No. & Newspaper & Frequency \\
\hline 1 & The Nation & 141 \\
2 & The News & 123 \\
& Grand Total & $\mathbf{2 6 4}$ \\
\hline
\end{tabular}

Table No: 2

Urdu Borrowed Words Used in The Nation

\begin{tabular}{lll}
\hline Sr. No. & Newspaper & Frequency \\
\hline 1 & Hard News & 83 \\
2 & Soft News & 58 \\
& Grand Total & $\mathbf{1 4 1}$ \\
\hline
\end{tabular}

Table No: 3

Urdu Borrowed Words Used in The News

\begin{tabular}{lll}
\hline Sr. No. & Newspaper & Frequency \\
\hline 1 & Hard News & 68 \\
2 & Soft News & 55 \\
\hline
\end{tabular}


Table No: 4

Details of Urdu Barrowed Words used in Soft News by the Selected Newspapers

\begin{tabular}{|c|c|}
\hline Urdu Words & Meaning \\
\hline Jawan & Soldier \\
\hline Gutka & Mixture of tobacco \\
\hline Sufi & A Muslim ascetic or mystic \\
\hline Mohalla & A community or an area of town or village \\
\hline Zakat & The payment that is made under Islamic laws yearly and used for needy people. \\
\hline Shalwar & Pent or trouser \\
\hline Moong & A Small round green bean \\
\hline Ghee & A type of butter or oil used for cooking \\
\hline Tehsil & The administrative area in parts of Pakistan \\
\hline Halal & The meat of animals killed by proper Islamic laws. \\
\hline Melas & Festival or a fair \\
\hline
\end{tabular}

\section{Table No: 5}

Details of Urdu Barrowed Words used in Hard News by the Selected Newspapers

Urdu Words Meaning

Roti

Kebabs

Masala

Kabaddi

Qawwali

Jungli

Biryani

Haji

Tabla
Bread or a flat cooked round bread

A dish of pieces of meat or fish

A mixture of ground spices

Name of a sport

Devotional music

Wild or not educated

South Asian dish made up of rice, meat, and vegetables

People who perform Hajj

Pair of small drums played in South Asian areas 


$\begin{array}{ll}\text { Sahib } & \text { Used to address the status of man } \\ \text { Mujahidin } & \text { Soldiers fighting for Islamic beliefs } \\ \text { Nawabs } & \text { A Pakistani ruler during Mughal emperors } \\ \text { Bajra } & \text { Millet } \\ \text { Jawar } & \text { Name of a crop }\end{array}$

\section{Discussion and Conclusion}

The table describes the Urdu words and the frequency of words used in English newspapers of Pakistan. All these words are commonly used in both The Nation and The News on a daily basis. A total of 264 Urdu words have been borrowed in both newspapers, The Nation used $141 \mathrm{Urdu}$ words while The News used 123 words. The Nation used 83 Urdu borrowed words in hard news while 58 words in soft news, as compared to 68 words used in hard news and 55 words in soft news used by The News. The English newspapers are filled with a variety of Urdu borrowed words and all the variety of words borrowed by Pakistani newspapers are culture-specific and are not equivalent to British English. The study concludes that there are many words of Urdu which are now used in the English language. Meanings of borrowed words are almost similar in both languages English \& Urdu. The English newspapers of Pakistan have frequently used the lexical borrowing and have used some Urdu words in the English language. For the need and prestige of societies usually the commitments of lexical borrowing have been used for the easy understanding of people. So it is further strengthened that a new variety of English in Pakistani society. The vocabulary of English is enriched with the loan words taken from Urdu vocabulary. The above analysis shows that English newspapers in Pakistan have used many Urdu words to explain the specific terms. These words used on a daily basis in English newspapers to convey the message in better expressions. Vocabulary and language are interlinked or it can say as, without vocabulary, language cannot exist. Borrowing words from Urdu to the English language have some limitations as they have some strict grammar rules as Pakistani English variety seems to be changing and this is due to the native varieties and particularly due to the Urdu language. When two cultures or languages come into contact, they rise to new words or vocabulary. English is an international language used widely. Whether the speakers are natives or non-natives, both speak English as it has become a common language to communicate for everyone. The process of borrowing words begins when people speak common words with each other for their own convention. English varieties that exist in this World shows the influence of the local varieties and the local variety is the reason for the outcome for English variety. The results show that these borrowed words are just for convenience and for better expressions.

\section{Bibliography}

Akhtar, H. et., all. (2018). Language-mixing and its processes in Pakistani Urdu newspapers. Pakistan Business Review, 20 (2).

Baumgardner, R. (1993). The English Language in Pakistan. Oxford University Press.

Baumgardner. J, \& Shamim, F. (1993). The Urduization of English in Pakistan. In Baumgardner, J. (Ed.), The English language in Pakistan. Karachi: Oxford University Press.

Bhatia, T.K., \& Ritchie, W.C. (2004). Bilingualism in the media and advertising. In T.K. Bhatia \& W.C. Ritchie (Eds. ), The handbook of bilingualism. Malden: Blackwell.

Bhatia,T.K. (1992). Discourse functions and the pragmatics of mixing: advertising across cultures. World Englishes, 2 (3). 
Braj B. Kachru, (2011). The other Tongue: English Across Cultures, Champaign-Urbana: University of Illinois press.

Deterding, D. (2007). The vowels of the different ethnic groups in Singapore English. In Prescott, D., Kirkpatrick, A., Martin, I. \& Hashim A. (Eds.), English in Southeast Asia: Literacies, literatures and varieties. New Castle: Cambridge Scholars Publishing.

Kachru, B B. (1986). The alchemy of English: The spread, functions, and models of non-native Englishes. Uraba and Chicago Illionis: University of Illionis Press.

Kia, L. S. et al. (2011). Code-Mixing of English in the Entertainment News of Chinese Newspapers in Malaysia. International Journal of English Linguistics, 1(1).

Martin (1998). The use of English in written French advertising: A study of code switching, codemixing and borrowing in a commercial context. Studies in the linguistic sciences, 28 (1).

Mushtaq, H. \& Zahra, T. (2012). An Analysis of Code-Mixing in Television Commercials. Language in India, 12(11).

Rebuck, M. (2001). The function of English loan words in Japanese. NUCB/JLCC, 4(1).

Routledge, B. R. (2006). The Indigenization of English in Pakistan. World Englishes: Routledge.

Sebba, M. (2012). Multilingualism in written discourse: An approach to the analysis of multilingual texts. International Journal of Bilingualism 17 (1).

Shen, C. (2010). A Study of Chinese-English Code-switching in Chinese Sports News Reports. CrossCultural Communication, 6(4).

Tuchman, G. (1973). Making news by doing work: Routinizing the unexpected. The American Journal of Sociology. 79(1): 110-131. 